\title{
INFLUENCE OF LASER IRRADIATION ON OPTICAL PROPERTIES OF GaAsBi/GaAs QUANTUM WELLS
}

\author{
J. Aleknavičius ${ }^{a}$, E. Pozingyte ${ }^{b}$, R. Butkute ${ }^{b}$, A. Krotkus ${ }^{b}$, and G. Tamulaitis ${ }^{a}$ \\ a Institute of Photonics and Nanotechnology, Faculty of Physics, Vilnius University, Sauletekio 3, Vilnius, Lithuania \\ ${ }^{\mathrm{b}}$ Department of Optoelectronics, Center for Physical Sciences and Technology, Sauletekio 3, Vilnius, Lithuania \\ Email: renata.butkute@ftmc.lt
}

Received 14 February 2018; accepted 22 March 2018

\begin{abstract}
This paper is focused on investigation of the impact of laser irradiation on the structural and optical properties of bismide-based multiple quantum wells (MQWs). The MQW structures, composed of 5 GaAsBi quantum wells, $7 \mathrm{~nm}$ thick, separated by $10 \mathrm{~nm}$-thick GaAs barriers, were grown by molecular beam epitaxy on GaAs (100)-plane oriented semi-insulating substrates at $330^{\circ} \mathrm{C}$ temperature. The bismuth content in as-grown GaAsBi wells evaluated from the measurements of HR-XRD rocking curves was about 6\%. HR-TEM and AFM studies of the MQWs evidenced sharp interfaces between the wells and barriers, and a smooth, droplet-free surface, respectively. HR-TEM images also evidenced a homogeneous bismuth distribution in the wells. The spatially-resolved photoluminescence study of GaAsBi/GaAs MQWs revealed the enhancement of PL emission efficiency of up to $80 \%$ with no shift of the spectral position after intense laser irradiation. The obtained results were explained by improvement of the GaAsBi crystal quality.
\end{abstract}

Keywords: molecular beam epitaxy, quantum wells, atomic force microscopy, spatially-resolved photoluminescence

PACS: 68.37.Ps, 78.55.Cr, 81.07.St, 81.15.Hi

\section{Introduction}

Bismide semiconductor compound $\mathrm{GaAsBi}$ is a promising material for optoelectronic devices, especially for light emitters and detectors in the nearinfrared (NIR) spectral range for optical fibre systems [1]. The introduction of small percentage of bismuth into gallium arsenide modifies the valence band structure and significantly reduces the band gap of the compound (by up to $88 \mathrm{meV}$ per $1 \%$ of Bi for $x<0.4$ and about $65 \mathrm{meV}$ for $x>0.4$ ), while the electron transport properties remain actually unchanged 2-4. In addition, the bandgap variation with temperature is shown to be much smaller for GaAsBi than that for GaAs or InGaAsP [1, 5]. Moreover, a significant increase in the spin-orbit split-off energy is caused by introduction of Bi results in suppression of the Auger recombination processes in GaBiAs-based laser diodes [6].
Since relatively low temperatures $\left(<400^{\circ} \mathrm{C}\right)$ are necessary for the growth of GaAsBi compound, post-growth rapid thermal annealing (RTA) at higher temperatures $\left(>600^{\circ} \mathrm{C}\right)$ is expected to reduce the density of structural defects and improve the quality [7]. Photoluminescence (PL) intensity improvement after the RTA procedure has been demonstrated in both MOVPE and MBE grown GaAsBi samples [8-11]. However, the effect of annealing on GaAsBi structures is still not well understood. It was reported that the PL intensity improvement factor depended on the temperature used in the annealing process, while the optimum annealing temperature was shown to be dependent on the $\mathrm{Bi}$ content [9]. It was demonstrated that RTA also caused a blue shift of the PL band. Although, it is still not clear if the emission shift is related to the Bi out-diffusion or to the microscale changes in the GaAsBi structure [12]. For 
thin GaAsBi structures, a decrease of defect density has been claimed to occur during annealing [ 9 , 10]. The PL intensity improvement might be associated with the reduction of bismuth clusters, as well as with the removal of defects related to arsenic and gallium [12-14. The overall improvement in crystal quality during RTA might also be involved [7]. On the other hand, variation in the PL intensity with time has been observed in our previous study when exposing the GaAsBi layer or quantum structure to laser irradiation. Likely, this effect could be related to the changes in the crystalline structure of bismide under influence of a laser beam. To the best of our knowledge, the permanent influence of laser irradiation on GaAsBi layers or quantum structures has not been investigated yet. Moreover, a detailed study of the irradiation influence on the bismide crystalline structure and optical properties would be very useful for the development of opticallypumped laser diodes based on GaAsBi MQWs, which would be prospective sources operating in near- and mid-infrared regions.

This work is focused on the study of the impact of laser irradiation on GaAsBi/GaAs quantum wells. Photoluminescence spectroscopy with spatial resolution was used for monitoring the impact. Focusing the laser beam on a submicrometre-size spot enabled laser annealing of small spots on the sample surface, which were studied in reference to the surrounding unaffected areas. The PL intensity and band peak position, indicating possible traces of micro-scale changes inside GaAsBi structures, were compared.

\section{Experiment}

The $\mathrm{GaAs}_{0.94} \mathrm{Bi}_{0.06} \mathrm{MQW}$ structure was grown using the molecular beam epitaxy (MBE) technique SVT-A on a semi-insulating GaAs substrate. Before MQW deposition, the GaAs buffer layer of $200 \mathrm{~nm}$ in thickness was grown under typical conditions: at substrate temperature of $600^{\circ} \mathrm{C}$ and $\mathrm{As} / \mathrm{Ga}$ ratio exceeding 10 . Then, the process was interrupted for temperature reduction down to $330^{\circ} \mathrm{C}$ and stabilization of the stoichiometric $\mathrm{As} / \mathrm{Ga}$ flux ratio; both these conditions are necessary for introduction of $\mathrm{Bi}$ atoms. The MQW structure consisted of five $7 \mathrm{~nm}$-wide quantum wells separated by $10 \mathrm{~nm}$-thick GaAs barriers grown at the same temperature as the quantum wells. Finally, the MQWs were covered by $5 \mathrm{~nm}$ thick high-temperature-grown GaAs. The structure of as-grown MQWs was characterized by means of high resolution X-ray diffraction (HRXRD) and high resolution transmission electron microscopy (HR-TEM). The bismuth content in GaAsBi wells evaluated from the HR-XRD rocking curves of (400) reflex was 6\%. The HR-TEM and AFM study evidenced sharp well/barrier interfaces and a smooth, droplet-free surface, respectively. The HR-TEM images also evidenced a homogeneous bismuth distribution in the wells.

The spatial distribution of PL characteristics was studied on a submicrometre scale using a microscopic system WITec Alpha 300 S operated in a confocal mode. A CW He-Cd laser emitting at $442 \mathrm{~nm}$ was used for excitation, and an objective of a high numerical aperture $(\mathrm{NA}=0.8)$ was used to ensure the lateral spatial resolution of $490 \mathrm{~nm}$. To perform the measurements with spectral resolution, the confocal microscope was coupled by an optical fiber to an Andor spectrometer followed by a thermoelectrically cooled InGaAs CCD camera capable of acquiring a PL signal in the NIR spectral region. The surface topography of the sample was investigated using a conventional contact-mode AFM incorporated in the WITec system. Special marks were used to match the mapping images of PL characteristics (intensity, band peak position, band width) measured in a confocal mode and the mappings of surface morphology within the same area, which were obtained using AFM.

To study the influence of laser irradiation, small spots, $350 \mathrm{~nm}$ in diameter, on the sample surface were affected using the He-Cd laser radiation. In the first set of measurements, each spot was exposed to irradiation for $30 \mathrm{~min}$ but at different laser power densities ranging from 0.3 to $2.0 \mathrm{MW} / \mathrm{cm}^{2}$. In the second set, the spots were irradiated for different durations from 1 to $45 \mathrm{~min}$ at the same radiation power density of $2.0 \mathrm{MW} / \mathrm{cm}^{2}$. The spacing between the laser treated spots was $10 \mu \mathrm{m}$. The treatment and measurements were performed in air at room temperature. The employment of the microscopic system enabled observation of the changes in PL properties in real time during the laser exposure. A detailed mapping of the PL parameters was performed after the irradiation of all spots on the sample. It has 
been carried out under excitation intensity low enough to avoid further annealing due to the PL excitation.

The change in composition within the affected spots was detected by scanning Kelvin force microscopy (SKFM) using a scanning probe microscope DM3100/Nanoscope IVa by Veeco Metrology Group. In the SKFM experiments, the contact potential difference (CPD) between the probe and sample surface was evaluated simultaneously with the surface topography.

\section{Results and discussion}

The PL spectrum of the sample under study consists of a single PL band centred at $1050 \mathrm{~nm}$. The PL mapping images show that the spatial distribution of the spectrally-integrated PL intensity in the unmodified areas of the sample is homogeneous: the standard deviation of the intensity is as low as $2 \%$. The spectrally-integrated PL intensity mapping image containing both sets of the spots modified by laser radiation is presented in Fig. 1. All the affect- ed spots exhibit a significant enhancement of PL intensity. The profiles of each spot along the horizontal lines (as indicated by a white dashed line for one spot) are presented in Fig. 1, besides the corresponding spot on the mapping image. The profiles were compared by studying two parameters: the peak increase in intensity (the amplitude of the profile) and the total intensity increase (the integral of the profile). The dependences of these parameters on irradiation conditions are summarized in Fig. 2( $a, b)$.

As seen in Fig. 2(a), the peak intensity initially increases with irradiation duration and tends to saturate at approximately $80 \%$ (green line online). The dips in the profiles of the spots exposed with the highest laser power densities (see the profiles for spots A1 and A2 in Fig. 1) are probably caused by the saturation. Meanwhile, the total increase in PL intensity grows nearly linearly with the exposition duration (red line online). This is an indication that the saturation at the centre of the spot is followed by expansion of the area of improved PL intensity.
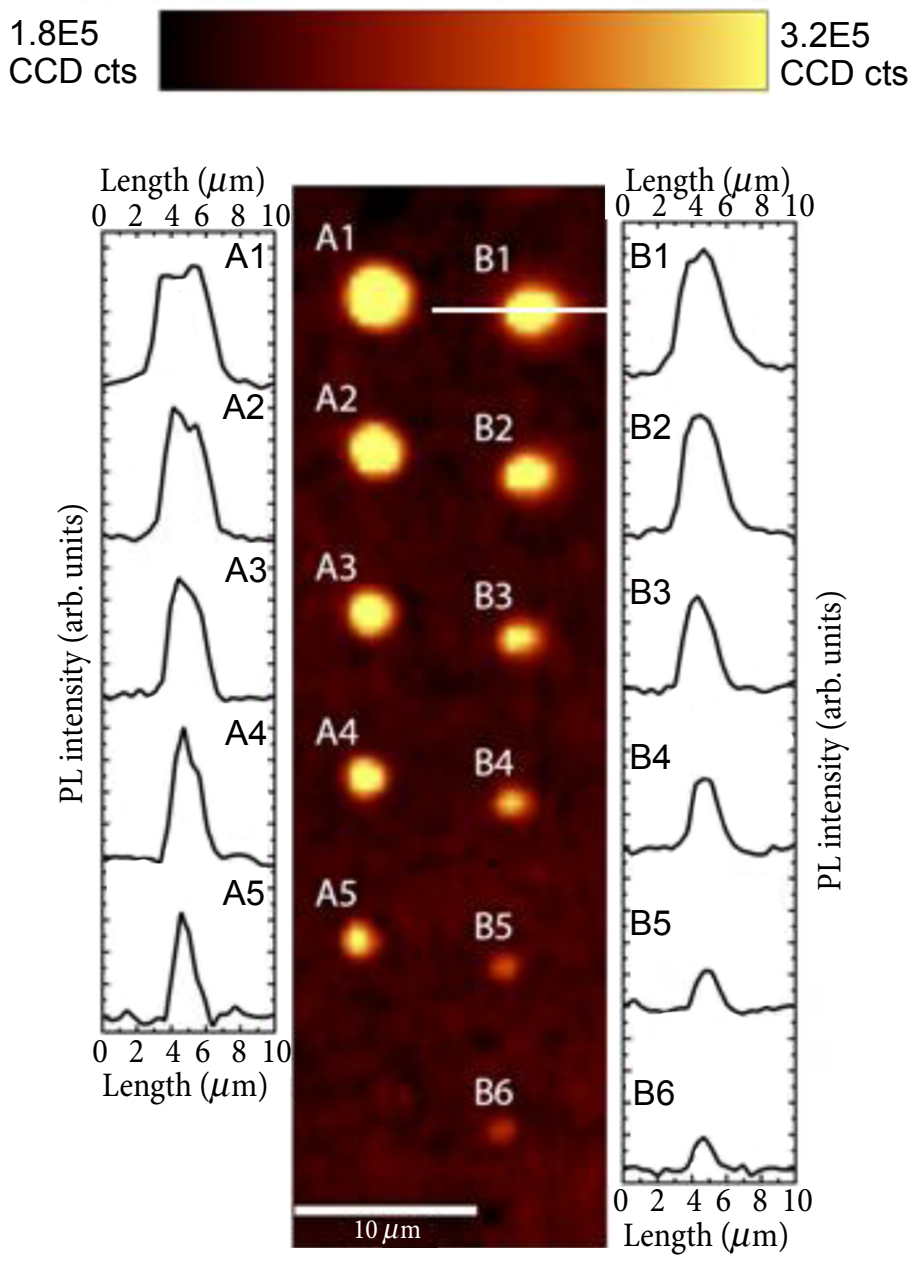

Fig. 1. The spectrally integrated PL intensity mapping image and intensity profiles of the corresponding irradiated spots. The laser power density varied between 0.3 and 2.0 MW/ $\mathrm{cm}^{2}$ for the spots in the left-hand column, while the duration varied from 1 to $45 \mathrm{~min}$ for the spots in the right-hand column. 

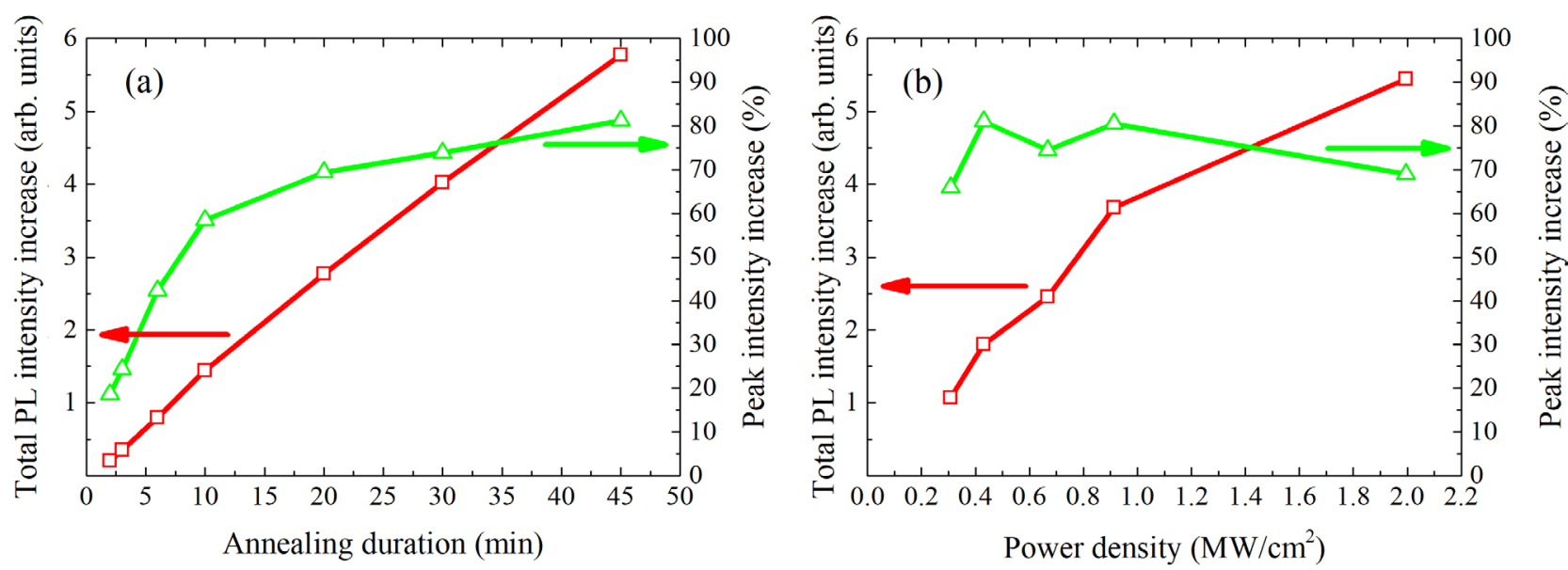

Fig. 2. Dependences of the total increase in PL intensity (red line online) and the peak increase in intensity (green line online) on irradiation duration (a) and laser power density (b).

The increase in the PL peak intensity does not depend on the laser power density (see a green line in Fig. 2(b)). For all the spots, the enhancement is between 65 and $80 \%$, i.e. close to the saturation level. Meanwhile, the total increase in PL intensity grows nearly linearly, similarly to its growth at increasing the exposition duration. These results suggest that the peak intensity increase is limited, and the limit could not be passed either by the increase of power density or duration. The increment of these parameters results just in extension of the modified area.

The laser irradiation also results in a blue shift of the PL band, as demonstrated for the spectral centre of mass in Fig. 3(a). The shift is approximately $4 \mathrm{meV}$ in a wide range of the exposed power densities and durations. Meanwhile, a weak red shift in the PL peak position is observed around the central spot area strongly affected by the laser beam.

The surface topography image of the same area as in Fig. 3(a) is shown in Fig. 3(b). Humps of up to $40 \mathrm{~nm}$ in height are evident at the irradiated spots. Both height and width of the humps increase with duration, while the height is approximately the same for all the spots exposed at different laser power densities.

The enhancement of PL intensity might be explained by assuming that the laser irradiation improves the crystalline quality of GaAsBi MQWs by enhancing the diffusion of $\mathrm{Bi}$ atoms, like during the rapid thermal annealing.

Temperatures of $600-700^{\circ} \mathrm{C}$ used in rapid thermal annealing were shown to be sufficient for the restructuration of GaAsBi structures [9, 12]. Since the photon energy of $\mathrm{He}-\mathrm{Cd}$ laser radiation

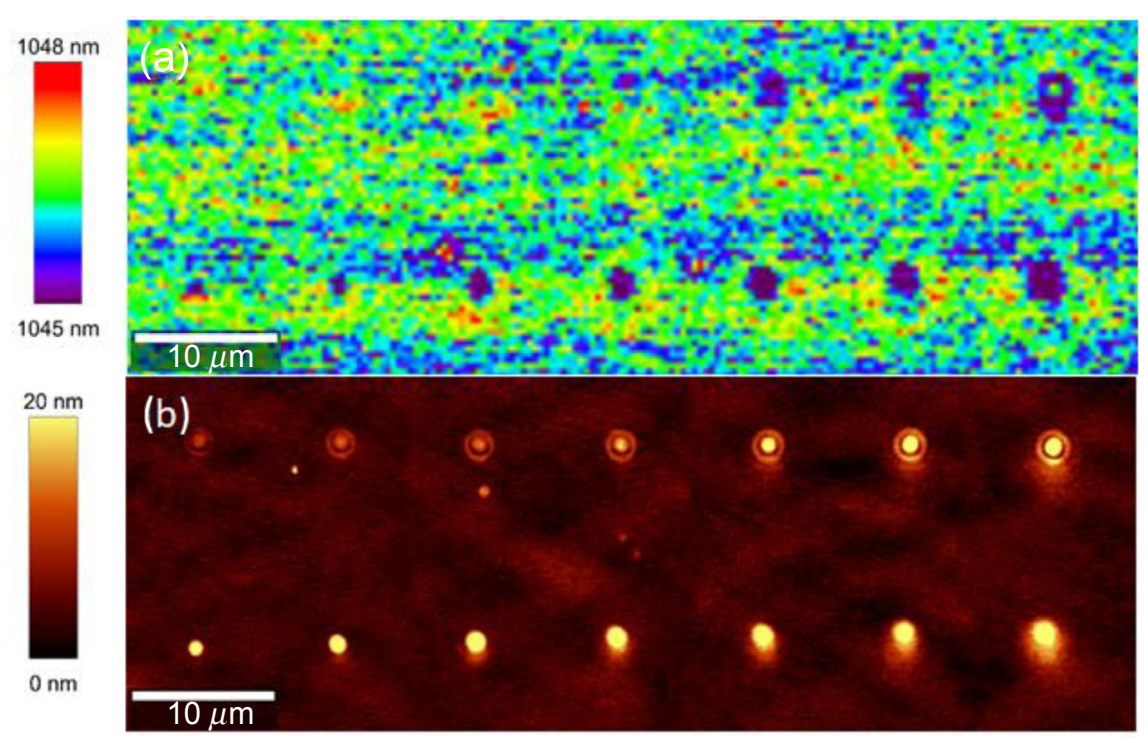

Fig. 3. The spectral centre of the mass mapping image (a) and AFM surface image (b) of the sample area with laser-annealed spots. The annealing duration varied for the spots on the top row, while the laser power density varied in the bottom row. 
is $2.80 \mathrm{eV}$ and the bandgap of the GaAsBi MQWs used in this study is approximately $1.18 \mathrm{eV}$, more than half of the excitation photon energy is transferred to the crystal lattice during thermalization of the photoexcited carriers. In addition, the thermal conductivity of $\mathrm{GaBi}$ is comparatively low. Thus, the annealing effect might be achieved in this material at comparatively low temperatures [16, 17] presumably achieved in our laser annealing experiments.

The increase of PL intensity within the affected spots indicates that typical defects, such as $\mathrm{Bi}$ pairs or clusters, are possibly eliminated by laser annealing. Moreover, the heating under laser irradiation supposedly enhances the migration of $\mathrm{Bi}$ atoms in GaAsBi QWs in plane and to the GaAs barrier, and, consequently, results in bismuth depletion at the exposed spots, as indicated by a blue shift in the spectral position of the PL band (see Fig. 6(b)). Hence, the decrease in defect density might be accompanied by lateral out-diffusion of $\mathrm{Bi}$ atoms to the surrounding area of the annealed spots. In addition, the PL intensity improvement might also be related to the reduction of non-bismuth related defects, such as arsenic antisites [9].

The peculiarities of the sample surface topography are in line with the possibility of bismuth migration perpendicularly to the sample surface. New structures on the sample surface are probably formed due to this diffusion of $\mathrm{Bi}$ atoms. The effect of Bi redistribution can be attributed to the inhomogeneous heating of the sample.
The surface is heated by the laser beam to a higher temperature than that deeper in the MQW structure, thus the thermogradient effect (TGE) might occur: the atoms with a bigger covalent radius in comparison to the host atoms drift along the gradient of temperature. In the case of $\mathrm{GaAsBi}$, Bi has the biggest radius in the compound and, therefore, the diffusion of bismuth atoms towards the higher temperature region is expected [18]. Thus, the formation of humps might be related to the gathering of $\mathrm{Bi}$ atoms at the surface of the capping layer. This assumption is supported by the measurements of contact potential difference (CPD) on the areas surrounding the annealed points. A typical CPD mapping image and the corresponding surface topography image are shown in Fig. 4 (note that the CPD scale is arbitrary, with zero set at the unmodified areas of the sample). The work function extracted from the CPD measurements is evidently decreased in the vicinity of the annealed spot. The decrease of the work function is most probably associated with the locally increased bismuth content in the top layers of the GaAsBi structure.

As pointed out before, the set-up exploited in our PL experiments provides a possibility to observe the changes of PL spectrum at the focal point during the irradiation. Typical time dependences of the spectrally integrated PL intensity (red curve online) and the spectral center of mass (green curve online) on the time of laser annealing are presented in Fig. 5. In the course of time, the spectrally integrated intensity grows in two linear stages

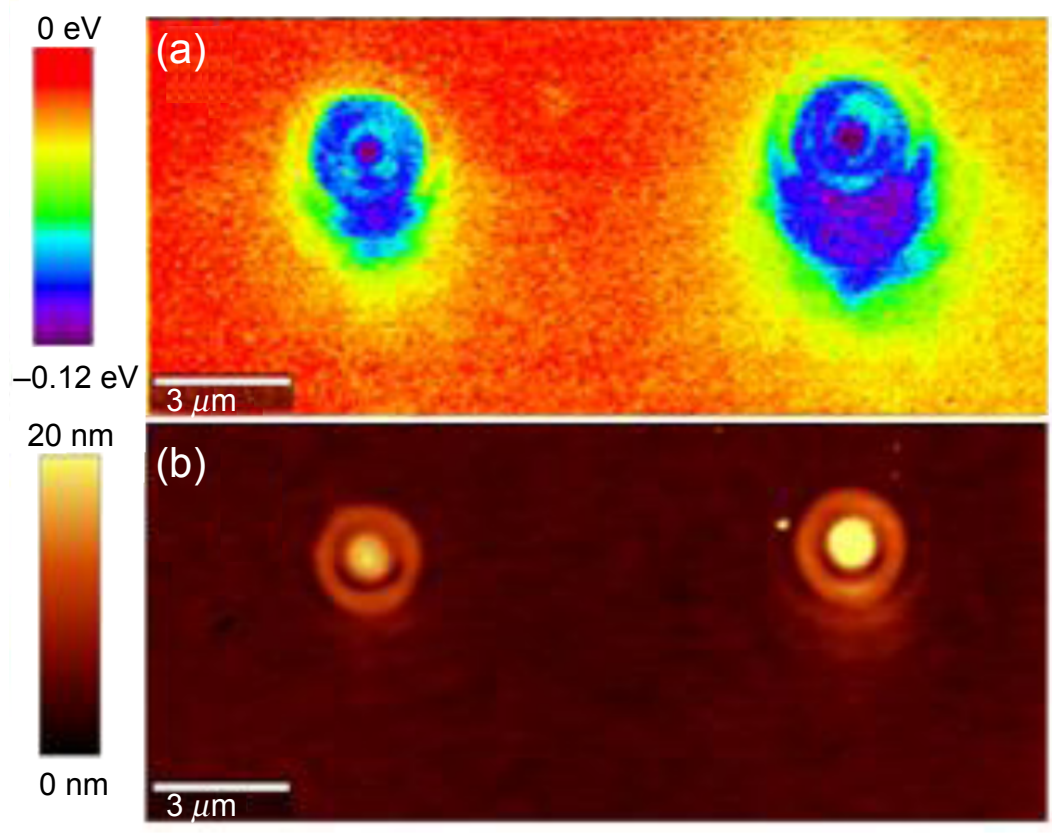

Fig. 4. Images of the contact potencial difference (a) and surface morphology (b) showing a decrease of the work function at two laser irradiated spots (see the top scale). 


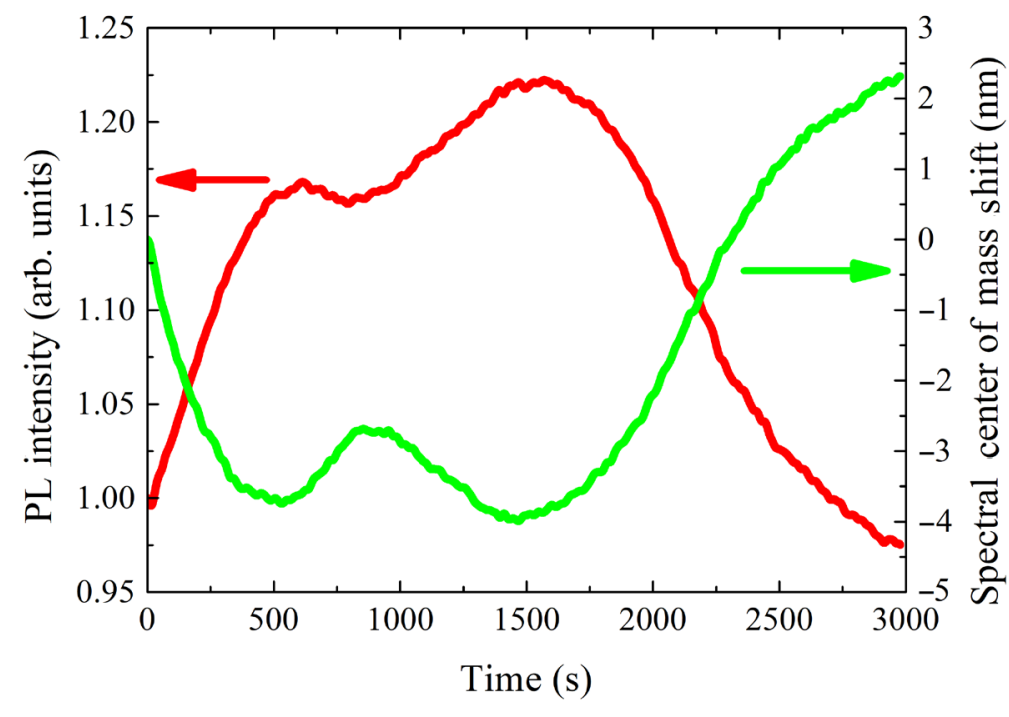

Fig. 5. Typical time dependence of the spectrally integrated PL intensity (red curve online) and the spectral centre of mass (green curve online) during the laser irradiation process. and starts decreasing after approximately $25 \mathrm{~min}$ of exposure. Furthermore, the spectral centre of mass rigorously follows the dynamics of PL intensity. The dual nature of the intensity growth in Fig. 5 might be related to elimination of defects (e.g. Bi pairs or larger clusters). The slopes of different steepness could be associated with different decomposition rates for various defects. The further rapid decline of PL intensity is most probably caused by disintegration of the QW structure originating from the formation of new defective regions. The behaviour of the spectral position is similar to the one seen in Fig. 3(a): the increase of PL intensity is accompanied by a blue shift of the PL peak. Note, however, that the shift of the PL peak is minor, so the change in the spectral position is insignificant. Therefore, the possibility to improve the PL emission efficiency by laser annealing is encouraging for application and can be obtained without compromising the PL band wavelength.

The best enhancement of the peak PL intensity up to approximately $80 \%$ has been achieved in our experiments after the $30 \mathrm{~min}$ exposure to a laser radiation power density of $1 \mathrm{MW} / \mathrm{cm}^{2}$. The time evolution of PL parameters in this case is presented in Fig. 6. Note that the blue shift of the PL peak after annealing is only $4 \mathrm{meV}$. The intensity increase and the spectral shift observed in this experiment is in consistence with the results obtained by thermal annealing of a sample of a similar composition, as reported in Ref. [9].

To summarize, the spatially-resolved photoluminescence study of GaAsBi MQWs revealed that the PL emission efficiency could be enhanced using laser irradiation by suppressing the nonradiative recombination at crystal defects. The results obtained in this work evidence a considerable enhancement of PL intensity varying from 65

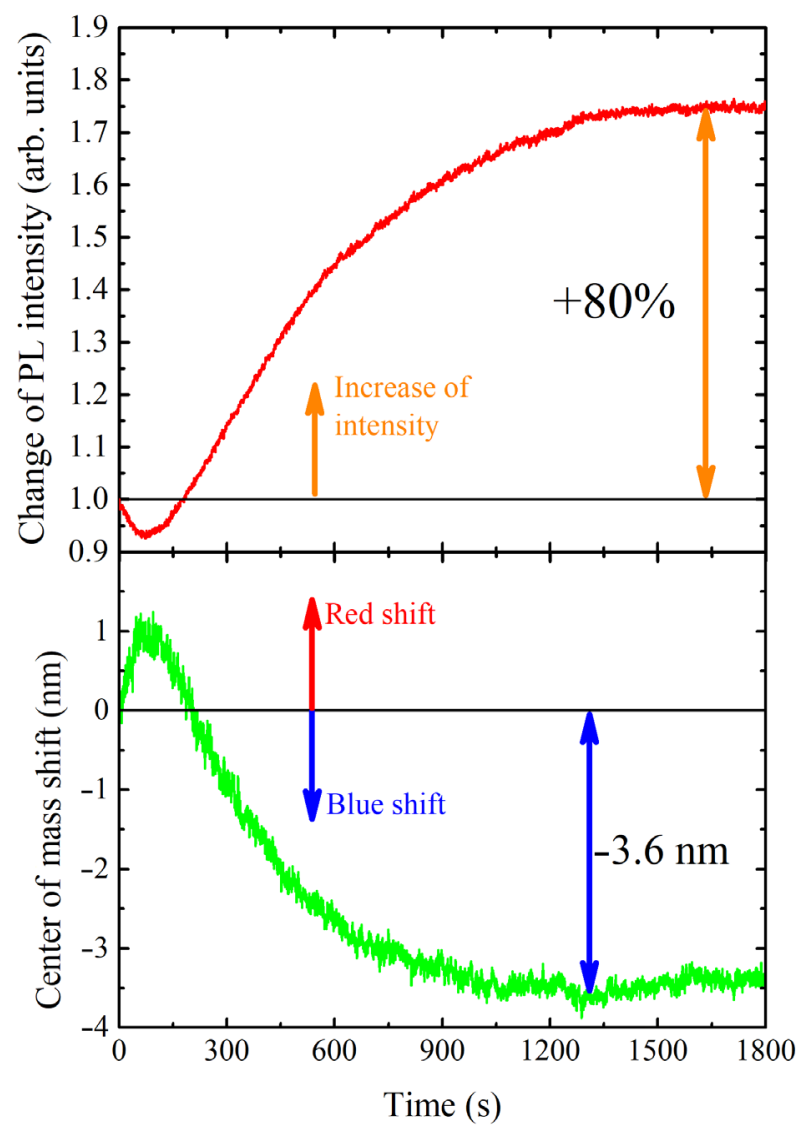

Fig. 6. Evolution of the spectrally integrated PL intensity (red curve online) and the spectral centre of mass (green curve online) with time of laser annealing. 
to $80 \%$ with an insignificant shift in the spectral position of the PL peak. The enhancement is interpreted by the laser-heating-induced migration of bismuth atoms from the pair and cluster sites to the As substitutional sites. It is also demonstrated that laser irradiation can be used as a site-selective alternative for the high-temperature annealing to improve the GaAsBi crystal quality.

\section{Acknowledgements}

The support of the Research Council of Lithuania under the Grant DOTSUT-236 No. 09.3.3-LMT$\mathrm{K}-712-01-0032$ is acknowledged.

\section{References}

[1] K. Oe and H. Okamoto, New semiconductor alloy $\mathrm{GaAs}_{1-x} \mathrm{Bi}_{x}$ grown by metal organic vapor phase epitaxy, Jpn. J. Appl. Phys. 37-2(11A), L1283L1285 (1998).

[2] S. Tixier, M. Adamcyk, T. Tiedje, S. Francoeur, A. Mascarenhas, P. Wei, and F. Schiettekatte, Molecular beam epitaxy growth of $\mathrm{GaAs}_{1-x} \mathrm{Bi}_{x^{\prime}}$ Appl. Phys. Lett. 82(14), 2245 (2003).

[3] K. Alberi, J. Wu, W. Walukiewicz, K.M. Yu, O.D. Dubon, S.P. Watkins, C.X. Wang, X. Liu, Y.-J. Cho, and J. Furdyna, Valence-band anticrossing in mismatched III-V semiconductor alloys, Phys. Rev. B 75(4), 045203 (2007).

[4] K. Alberi, O.D. Dubon, W. Walukiewicz, K.M. Yu, K. Bertulis, and A. Krotkus, Valence band anticrossing in $\mathrm{GaBi}_{x} \mathrm{As}_{1-x}$, Appl. Phys. Lett. 91(5), 051909 (2007).

[5] J. Yoshida, T. Kita, O. Wada, and K. Oe, Temperature dependence of $\mathrm{GaAs}_{1-x} \mathrm{Bi}_{x}$ band gap studied by photoreflectance spectroscopy, Jpn. J. Appl. Phys. 42-1(2A), 371-374 (2003).

[6] Z. Batool, K. Hild, T.J.C. Hosea, X. Lu, T. Tiedje, and S.J. Sweeney, The electronic band structure of $\mathrm{GaBiAs} / \mathrm{GaAs}$ layers: Influence of strain and band anti-crossing, J. Appl. Phys. 111(11), 113108 (2012).

[7] G. Feng, K. Oe, and M. Yoshimoto, Influence of thermal annealing treatment on the luminescence properties of dilute GaNAs-bismide alloy, Jpn. J. Appl. Phys. 46(32), L764-L766 (2007).
[8] I. Moussa, H. Fitouri, Z. Chine, A. Rebey, and B. El Jani, Effect of thermal annealing on structural and optical properties of the $\mathrm{GaAs}_{0.963} \mathrm{Bi}_{0.037}$ alloy, Semicond. Sci. Technol. 23(12), 125034 (2008).

[9] A. Mohmad, F. Bastiman, C. Hunter, R. Richards, S. Sweeney, J. Ng, and J. David, Effects of rapid thermal annealing on $\mathrm{GaAs}_{1-x} \mathrm{Bi}_{x}$ alloys, Appl. Phys. Lett. 101(1), 012106 (2012).

[10]S. Mazzucato, P. Boonpeng, H. Carrère, D. Lagarde, A. Arnoult, G. Lacoste, T. Zhang, A. Balocchi, T. Amand, X. Marie, and C. Fontaine, Reduction of defect density by rapid thermal annealing in GaAsBi studied by time-resolved photoluminescence, Semicond. Sci. Technol. 28, 22001 (2013).

[11]O.M. Lemine, A. Alkaoud, H.V. Avanço Galeti, V. Orsi Gordo, Y. Galvão Gobato, H. Bouzid, A. Hajry, and M. Henini, Thermal annealing effects on the optical and structural properties of (100) $\mathrm{GaAs}_{1-x} \mathrm{Bi}_{x}$ layers grown by molecular beam epitaxy, Superlattices Microstruct. 65, 48-55 (2014).

[12]H. Makhloufi, P. Boonpeng, S. Mazzucato, J. Nicolai, A. Arnoult, T. Hungria, G. Lacoste, C. Gatel, A. Ponchet, H. Carrere, X. Marie, and C. Fontaine, Molecular beam epitaxy and properties of $\mathrm{GaAsBi} / \mathrm{GaAs}$ quantum wells grown by molecular beam epitaxy: effect of thermal annealing, Nanoscale Res. Lett. 9(1), 123 (2014).

[13]R. Butkute, V. Pačebutas, B. Čechavičius, R. Adomavičius, A. Koroliov, and A. Krotkus, Thermal annealing effect on the properties of GaBiAs, Phys. Status Solidi C 9(7), 1614-1616 (2012).

[14]S.G. Spruytte, C.W. Coldren, J.S. Harris, W. Wampler, P. Krispin, K. Ploog, and M.C. Larson, Incorporation of nitrogen in nitride-arsenides: Origin of improved luminescence efficiency after anneal, J. Appl. Phys. 89(8), 4401 (2001).

[15]R. Butkutè, A. Geižutis, V. Pačebutas, B. Čechavičius, V. Bukauskas, R. Kondrotas, P. Ludewig, K. Volz, and A. Krotkus, Multi-quantum well $\mathrm{Ga}(\mathrm{AsBi}) / \mathrm{GaAs}$ laser diodes with more than $6 \%$ of bismuth, Electron. Lett. 50(16), 1155-1157 (2014).

[16]C. Toher, J.J. Plata, O. Levy, M. de Jong, M. Asta, M.B. Nardelli, and S. Curtarolo, High-throughput 
computational screening of thermal conductivity, Debye temperature and Grüneisen parameter using a quasi-harmonic Debye model, Phys. Rev. B 90, 174107 (2014).

[17]P. Dongmo, Y. Zhong, P. Attia, C. Bomberger,

R. Cheaito, J.F. Ihlefeld, P.E. Hopkins, and J. Zide,
Enhanced room temperature electronic and thermoelectric properties of the dilute bismuthide InGaBiAs, J. Appl. Phys. 112(9), 093710 (2012).

[18]S. Francoeur, S. Tixier, E. Young, T. Tiedje, and A. Mascarenhas, $\mathrm{Bi}$ isoelectronic impurities in GaAs, Phys. Rev. B 77, 085209 (2008).

\title{
LAZERIO SPINDULIUOTĖS POVEIKIS KVANTINIŲ GaAsBi/GaAs DUOBIŲ OPTINĖMS SAVYBĖMS
}

\author{
J. Aleknavičius ${ }^{\mathrm{a}}$, E. Pozingyte ${ }^{\mathrm{b}}$, R. Butkute ${ }^{\mathrm{b}}$, A. Krotkus ${ }^{\mathrm{b}}$, G. Tamulaitis ${ }^{\mathrm{a}}$ \\ ${ }^{a}$ Vilniaus universiteto Fotonikos ir nanotechnologiju institutas, Vilnius, Lietuva \\ ${ }^{\mathrm{b}}$ Fiziniu ir technologijos mokslu centro Optoelektronikos skyrius, Vilnius, Lietuva
}

\section{Santrauka}

Šiame darbe tyrème lazerio spinduliuotès poveiki bismidų junginių kvantinių darinių kristalinei sandarai ir optinems savybems. Kvantini darini sudare GaAsBi junginio $7 \mathrm{~nm}$ pločio 5 kvantinès duobès, apgaubtos $10 \mathrm{~nm}$ pločio GaAs barjerais. Dariniai buvo auginami esant $330^{\circ} \mathrm{C}$ temperatūrai, molekulinių pluoštelių epitaksijos būdu ant pusiau izoliuojančio GaAs padèklo, orientuoto (100) plokštuma. Bismuto kiekis kvantinèse GaAsBi duobèse, i̇vertintas modeliuojant didelès skyros rentgeno spindulių difrakcijos (400) plokštumos atspindžio smailès kampinę difrak-
\end{abstract}

togramą, buvo $6 \%$. Didelès skyros peršviečiamosios elektronų ir atominiu jęgu mikroskopijos tyrimai parodė aštrias sąlyčio tarp kvantinės duobės ir barjeru ribas, glotnu ir be segregavusio bismuto ar galio lašu darinio paviršiuc. Elektronų mikroskopijos tyrimai taip pat atskleidè tolygų bismuto pasiskirstymą kvantinèse GaAsBi duobėse. Kampinès skyros fotoliuminescencijos matavimai parodè, kad lazerio spinduliuotè gali suintensyvinti emisija iš kvantiniu GaAsBi/GaAs darinių net iki $80 \%$ nedarant poveikio emisijos bangos ilgiui. Darbe pasiekti rezultatai pagrịsti GaAsBi junginio kristalinès gardelès susitvarkymu. 